\title{
Protective Effect of Vitamin C and Ginseng on Experimental Liver and Kidney Injuries Induced by Insecticide Profenophos In Male Rats
}

\author{
Fatma A. Morsy \\ Pathology Department, National Research Center
}

\begin{abstract}
The present investigation deals with histopathological and histochemical studies of profenophos on liver and kidney of male albino rats and the protective effects of vitamin $\mathrm{C}$ and ginseng to reduce the deleterious effect induced by profenophos. Oral administration of profenophos at dose level of $1 / 10$ LD50 for 15 successive days induced histological changes in liver and kidney. No histological or histochemical change could be detected in liver and kidney of rats treated with each of vitamin $\mathrm{C}$ and ginseng. Profenophos treatment also resulted in histochemical changes in liver and kidney including decrease in protein granules and marked decrease in DNA and mucopolysaccharides content.

Administration of vitamin C (0.01/ $100 \mathrm{~g} \mathrm{b.w})$ and ginseng $(20 \mathrm{mg} / \mathrm{kg} \mathrm{b} . \mathrm{w})$ to profenophos treated animals resulted in an improvement in histological picture of liver and kidney as well as the histochemical parameters.
\end{abstract}

\section{Introduction}

Pesticides are toxic chemical which have been used extensively to increase food production and improve the quality of agricultural crops, and have become an integral part of modern farming. They are generally used to control insects of food crops, fiber crops, soils, pastures and forests (Akhter, 1985). Pesticides are mainly used in agriculture (68\%), in commercial and in industrial activities $(17 \%)$, domestically $(8 \%)$ and $(7 \%)$ in governmental application (cantoni and Comi, 1997).

Also, these pesticides are chemical hazardous consequences as they may be the cause of death both through accidental or international ingestion (Sullivan and Blose, 1992). Each pesticide had a specific pattern of affinity for different tissues (GarciaRepetto et al., 1995).

Organophosphorous compounds represent a large proportion of insecticides used all over the world (Gralewicz and Socko 1997). The lethality of organophosphorous comp ounds has been attributed to their inhibitory effect on a cetylcholines terase (AchE) in the nervous system which is responsible for the inactive ation of neurotransmitter a cetylcholin (Liu et al., 1994 and Aschner, 2000).

Profenophos, which is the pesticide of choice in the present study, is a widely organophosphorous insecti cide used in Egypt for the control of various caterpillars, white fly and mites on cotton and vegetable crops (British crop protection conuncil, 1991). In animal studies, many pesticides are carcinogenic (e.g organophlorines, creosote and sulfallate) while other (notably, the organochlorines, DDT, chlordane and lindane) are tumor promoters (Dich et al., 1997). Both dimethyl methyl phosphonate (DMMP) and trimethyl phosphate (TMF) are 
organophosphorous compounds that can evoke sterility in male rodent (Cho and Park 1999). The organophosphorous compounds has been found to inhibit the mitotic activity and cause chromo somal aberrations (Aschner, et al., 2000).

Antioxidants have been reported to play significant role in protection against damage from lipid peroxidation. Ascorbic acid (vitamin C) is a major circulating water soluble antioxidants. Vitamin $C$ exerts protective role against organophosphorous pesticides (Kurata et al., 1993). Moreover vitamin C abolishes chromosome damaging resu lted from the effect of toxic substance (Tromner et al, 2002), oxidative DNA damage (Sxi et al., 1992 and Meves et al., 2002). Vitamin $C$ seems to reduce the incidence of fragmentation and subsequent rearrangements induced by the pesticides (Onosaka et al., 1987 and Zhang et al., 2001).

Ginseng saponins is a potent antioxidant and effective to reduce tissue damage induced by free radical (Chang et al., 1999 and Sohn et al., 1993). It was reported that ginseng has a protective effect against many toxicants in human and experimental animals (Jeong et al., 1997), and can increase body resistance to many harmful factors and can protect tissues from damage when an organism is in stress (Liu et al., 1995). It reduces chromosomal aberrations induced by some chemicals (Umnova et al., 1991). Ginseng have antitumor promoting activity (Konoshima et al., 1999) and induced radioprotective effect on skin (Kim et al., 1999), and suppression of spontaneous liver tumor formation in male mice (Nishino et al., 2001), and could enhance immuno function of human body (Xiaoguang et al., 1998).

The present study is conducted to investigate possible protective effect of vitamin $\mathrm{C}$ and ginseng root against organophosphorous pesticide (Profeno phos) toxicity particularly on liver and kidney of male albino rats.

\section{Materials And Methods}

72 male albino rats weighting $120-150 \mathrm{~g}$ were used in this study. The animals were assigned into six groups. Each group contained 12 rats. Rats were treated daily for 15 days as follows: group (1) Animals of the first group were kept as control, group (2) Rats of the second group were given $1 / 10$ LD50 of profenophos daily for 15 successive days $(\mathrm{LD} 50=867.8 \quad \mathrm{mg} / \mathrm{kg} \quad$ b.w $)$ according to (Farrage, 1996), group (3) was given vitamin $\mathrm{C}$ at a dose level of $0.01 \mathrm{~g} / 100 \mathrm{gb} . \mathrm{w}$ (Padget and Barnes 1964) by stomach tube, $10 \mathrm{~min}$ before profenophos administration daily for 15 successive days, group (4) was given ginseng $(20 \mathrm{mg} / \mathrm{kg} \mathrm{b.w}) 10 \mathrm{~min}$ before profenophos administration, group (5) was given vitamin $\mathrm{C}$ only at a dose level of $0.01 \mathrm{~g} / 100 \mathrm{gb} . \mathrm{w}$ by stomach tube daily for 15 successive days, group (6) was given ginseng only $(20 \mathrm{mg} / \mathrm{kg}$ b.w) by stomach tube daily for 15 successive days.

\section{studies :}

Histological and histochemcial

The liver and kidney of different groups were removed and fixed in $10 \%$ of saline formol, $5 \mu \mathrm{m}$ thick paraffin sections were stained with haematoxylin and eosin (Drury and Wallington 1980) and investigated by light microscope. Sections of liver and kidney were stained for mucopolysaccharides (MacManus and Cason, 1950), protein (Mazia et al., 1953) and DNA (Feulgen and Rosenbeck, 1942).

\section{Results}

\section{Histological results of the liver:}

The normal histological structure of the liver was observed in Fig. (1). 
No pathological changes could be noticed in the liver given each of vitamin $\mathrm{C}$ and ginseng.

The treatment of rats with profenophos only showed vacuolated hepatocytes and fatty change in the inner and outer regions of the lobules with congested portal tract. The cytoplasm and nuclei of hepatocytes exhibited pale stainability (Fig. 2). The dilated blood sinusoids are filled with red blood cells. Some hepatocytes showed focal necrosis, others showed pyknosis. Dilated and congested portal vessels were also present (Fig. 3).

The liver of rats subjected to vitamin $\mathrm{C}$ and profenophos, showed some protective effects as compared to the group of rats subjected to profen ophos only. they appeared in the form of marked diminution of the fatty change, increase in number of kupffer cells in dilated blood sinusoids, while many pyknotic nuclei could be detected (Fig. 4).

The liver of rats subjected to ginseng and profenophos showed some obvious pathological changes, but these changes were some whate less than those of rats treated with toxin only. Examination of liver sections showed dilatation and congestion of central vein. Dilated blood sinusoids was also noticed (Fig. 5).

\section{II- Histochemical results of the liver:}

Examination of control liver sections stained with periodic acid schiff's (PAS) showed mucopolysaccharides granules in the cytoplasm of hepatocytes; the peripheral zonal cells showed higher mucopolysaccharides content than the central zonal cells (Fig. 6A).

Daily administration of profen ophos only for 15 successive days induced decrease stainability of PAS+ve materials (Fig. 6B).

Daily treatment of rats with vitamin $C$ in combination with profen ophos showed moderate increase in mucopolysaccharides content in the cytoplasm of hepatocytes (Fig. 6C) and marked increase in mucopolysa ccharides content could be observed in the case of rats subjected to ginseng and profenophose as compared to rats subjected to profenophos only (Fig.6D).

Examination of control liver sections showed moderate protein content in the cytoplasm of hepatocytes. Some nuclei showed deep protein content (Fig. 7A). After daily treatment with an oral dose of profenophos for 15 successive days the protein inclusions showed marked diminution in liver cells and the staniability was mostly diffused (Fig.7B). Slight increase in protein content was recorded in the case of rats subjected to vitamin $\mathrm{C}$ in combination with profenophos as compared to rats subjected to profenophos only (Fig. 7C). Moderate increase in protein content in the cytoplasm of hepatocytes was also observed in the case of rats treated with ginseng in combination with profenophose as compared to rats subjected to profenophos only (Fig. 7D).

Normal distribution of DNA could be observed in (Fig. 8A). Daily treatment of rats with an oral dose of profenophos exhibited a decrease in DNA content in liver cells as compared to control (Fig.8B). Increase in DNA content was noticed in the case of rats subjected to vitamin $\mathrm{C}$ in combination with profenophos as compared to rats treated with profenophos only (Fig. 8C). The pretreatment of rats with ginseng in combination with profenophos showed that the DNA content appeared like control (Fig. 8D). 
III- Histological results of the kidney:

The normal histological structure of the kidney was observed in Fig.(9).

No pathological changes could be observed in the kidney given each of vitamin $\mathrm{C}$ and ginseng.

The kidney of the second group of animals daily treated with profenophos at dose level of $1 / 10$ LD50 for 15 successive days produced some glomerular degeneration, others showed mesangial hypercellularity and wide urinary space. Some tubular epithelial cells showed vacuolar degeneration, pyknosis and focal area of necrosis. Cell debris appeared in the lumen of tubules and in dilated interstitial space. Mononuclear cellular infiltration and haemorrhage in the interstitial tissue (Fig. 10 \&11). Concerning rats treated with vitamin $\mathrm{C}$ and profenophos in combination showed some protective effects appeared in comparison with group of rats treated with profenophos only. Examination of kidney sections showed glomerular lobulation. Focal necrosis in some tubular epithelial cells and vacuolar degeneration (Fig. 12).

The kidney of rats subjected to ginseng in combination with profen ophos showed some protective effects as compared to the group of rats treated with profenophos only. They appeared in the form of marked diminution of vacuolar degeneration, necrosis and glomerular degeneration. Interstitial and interglomerular haemor -rhage was also noticed, signs of degeneration could be observed in tubular epithelial cells (Fig. 13).

\section{Histochemical results of the kidney :}

The periodic acid Schiff's (PAS) technique was used to demonstrate the presence of polysaccharides in the kidney. The PAS+ve materials were mainly distributed at the brush border and basement membrane of the renal tubules (Fig. 14A).

Daily administration of profenophos only at dose level of $1 / 10$ LD50 for 15 successive days induced decrease stainability of PAS +ve materials (Fig. 14B). Moderate increase in polysaccharides content was observed in the group of rats treated with vitamin $\mathrm{C}$ in combinations with profenophos (Fig. 14C). Marked increase in polysaccharides content was recorded in case of rats treated with ginseng in combination with profenophos (Fig.14D).

In normal rat high protein inclusions in renal cells were localized in the cytoplasm and to lesser extent in their nuclei (Fig. 15A). Marked diminution of protein content was recorded in the case of rats treated with profenophos only (Fig. 15B). Concerning rats treated with each of vitamin $\mathrm{C}$ and ginseng in combination with profenophos sections showed an increase in protein content as compared to group of rats subjected to profenophos only (Fig. 15C,D).

Fig. (16A) shows the normal distribution of DNA in the kidney of control rat. Daily administration with an oral dose of profenophos equivalent to $1 / 10$ LD50 for 15 consecutive days induced a decrease in DNA content in kidney cells as compared to control (Fig. 16B).

The kidney of rats subjected to each of vitamin $\mathrm{C}$ and ginseng in combination with profenophos showed that DNA content appeared like the normal level (Fig. 16C).

\section{Discussion}

Pesticides have been widely used in agriculture and their background in their environment have increased. Therefore, they may be a source of many biochemical and physiological 
disturbances in animals and human (Zhao et al., 1987). Each pesticide had a specific pattern of affinity for different tissues (Garcia-Repetto et al., 1995 and Sies, 1985).

It has been observed in the present investigation that the organophosp horous insecticide, profenophos, induced histopathological and histoche mical changes in liver, kidney of male albino rats.

The microscopical appearance of liver in rat receiving $1 / 10$ LD50 of profenophos for 15 successive days was characterized by presence of small vacuoles and fatty changes in the inner and outer regions of the lobules. The dilated blood sinusoids are filled with red blood cells and central vein was also congested and dilated. Results of this work go in agreement with (Torki et al., 2001), they noticed that the treatment of rats with profenophos at dose level of $1 / 10$ LD50 for 90 successive days caused the presence of large amount of fine droplets of fats with necrosis of individual hepatocytes. Hassan et al., (1991) reported that the degeneration and necrotic changes with inflammatory cell infiltration were observed in liver and kidney of rats, mice, hamsters and guinea pigs after of oral administration of endrin at a dose level of $4 \mathrm{mg} / \mathrm{kg}$ body weight. They noticed also fatty changes in the form of hepatic foam cells with cytoplasmic vacuolation. Fatty changes were also detected in mice by Rashwan et al., (1992) using kepone. Moreover, the mechanism of fatty change is complex, the intracytoplasmic fat can detected due to a number of factors, e.g. organelles injury, metabolic disorders and, or deficiency of essential lipotropic factor. Such changes appear in hepatocyte cytoplasm as macrovesicular and/or microvesicular patterns (Gopinath et al., 1987 and Kumar et al, 1992).
In the present investigation the liver blood sinusoids are filled with red blood cells. A similar observation has been described by Rashwan et al., (1992), they concluded that the kepon injection to mice produced dilatation of the liver blood sinusoids.

Examination of liver section of profenophos intoxicated rats revealed pyknosis together with degenerated nuclei. Results of this work go in agreement with Farrag (1996) who found that the treatment of rats with single oral dose (LD50) of profenophos exhibited some pyknotic nuclei .

The present study showed that the renal tissue is adversely affected by the pesticide, profenophos. The histopath ological changes in the kidney of rats given an oral doses of profenophos showed vacuolar degeneration, pyknosis and focal area of necrosis in some tubular epithelial cells. In previous study the degeneration and necrosis of the renal tubules have also been observed by Fukuoka et al., (1987\& 1988) in rats using a single intraperitoneal dose of the organoph osphorous compound, tirs $(2,3$ dibromophenyl) phosphate. Degener ation and necrosis of the renal tubules had also been observed in rats given $200 \mathrm{mg} / \mathrm{kg} \mathrm{b} . \mathrm{w}$ of chloromethane diphosphate after 24 and 48 hours of treatment (Alden et al., 1989). According to Torki et al., (2001) the treatment of rats with profenophos at a dose level of $1 / 10$ LD50 for 90 successive days showing sever tubular nephrosis in distal and collecting tubules, a large fat droplets in renal tubular epithelium and vascular degeneration of glomerular tuft capillaries. Also intraluminal proten eous hyaline casts were present. Results of the present work go in agreement with Farrag, (1996) who found that the treatment of rats with a single oral dose 
of profenophos equivalent to LD50 and sacrificed after 24 hours showing the development of necrosis of epithelial cells of some proximal tubules. Signs of degeneration appeared in the form of pyknosis and karyolysis.

It is realized that the treatment of rats with vitamin $\mathrm{C}$ in the present experiment alleviated the deleterious effect of profenophos on the liver and kidney. Ascorbic acid may act as cofactor in the synthesis of biologically antioxidant materials such as glutathione (Kurata et al., 1993). Antioxidant are known to be able to reduce the incidence of fragmentation and subsequent rearrangement induced by pesticides(Onosaka et al, 1987). In addition, one of the principal biochemical reactions of ascorbic acid is to destroy toxic free radical resulting from the metabolic products of oxygen (Sapper et al., 1982). Electron scave nging activity of ascorbic acid is either directly, in competition with dissolved oxygen, or by an electron transfer action from the free radicals which leads to reduction in its concentration and tissue damage (Rijnkets et al., 2003). The main protective effect of ascorbic acid dose not result from direct scavenging but rather from the regeneration of vitamin E-radical (MC-Cay et al., 1979).

In the present work the treatment of rats with vitamin $\mathrm{C}$ and profenophos showed marked diminution of fatty changes in liver and decrease in pathological changes in kidney in comparison with group of rats subjected to profenophos only. According to Chakraborty et al., (1978), they found that vitamin $\mathrm{C}$ adverse some patholo gical changes induced in liver of rats intoxicated with parathion and malathion. The treatment of rats with high doses of ascorbic acid adverse some histological patterns of both liver and kidney tissues which were grossly ultered under chlordane toxicity [Chatlerjee et al., 1981], and in rats given endrin [Hassan et al., 1991]. However the results of Nagyova et al., (1994), they indicated that increased vitamin $\mathrm{C}$ intake could possibly reduce and prevent nephrotoxic effect.

The treatment of rats with ginseng conditioned the adverse effect of profenophos on the liver and kidney. This plant exerted its protective activity against pesticide either directly by inhibiting lipid peroxidation and scavenging free radicals (Keum et al., 2000 and Lee et al., 2002) or indirectly through enhancement of the activity of superoxide dismutase and an enzymatic free radicals scavenger in the cells (Xie et al., 1993).

Deng and Zhang (1991) \& Mattei et al., (1998) reported that ginseng can increase body resistance to many harmful factors and protect tissue from damage. According to Chang et al. (1999), the ginseng can induce the antioxidant enzymes which are important for maintaining cell viability by lowering the level of oxygen radical generated from intercellular metabo lism. The ginseng can inhibited apopt osis and suppressed hepatic necrosis [Tran et al., 2002].

Many vacuols could be detected in liver and kidney of rats treated with toxic material. These vacuols were demonstrated by Johonson et al., (1982), he stated that vacuolation may be due to altered permeability of the cell membranes which would allow increased fluid uptake.

Concerning histochemical results, the treatment of rats with profenophos only showed a decrease in glycogen content in the cytoplasm of hepatocytes and in the brush border and basement membrane of kidney. Results of this work go in agreement with Kotb et al., 
(1989) they noticed that the treatment of rats with the insecticide baygon led to depletion in the polysaccharides of kidney and liver. Aslight decrease in mucopolysaccharides content in the adrenal gland of rat after treatment with curacron was reported by El-Banhawy et al., (1990). According to Wu (1990) the mucopolysaccharides inclusion disappeared in the muscle of worker exposed to methamidophos. In general, the reduced carbohydrate components under the effect of pesticide could be due to the release of hydrolytic enzymes from ruptured lysosomes under the toxic effect of toxic agents [Sivaparasado et al. 1983 and Shalaby, 1985]. According to Rashwan et al., (1992) the treatment of rats with kepone showed decrease in glycogen content in liver as detected by decrease affinity to PAS reaction.

The treatment of rats with each of vitamin $\mathrm{C}$ and ginseng in combination with organophosphorous (profenophos), the glycogen content increase in liver and kidney in comparison with group of rats subjected to profenophos only. This in agreement with Zhang (1992) who stated that the ginseng had a protective effects on the mitochondria which being less damaged.

Histochemical investigation of total proteins of the liver and kidney of rats treated with profenophos showed that there is a weak reactivity of protein contents in these organ. El Ganzari (1975), reported that a marked loss in the protein content of the liver cells was noticed in rats given one dose of lindane or tamaron. Joshi and Desai, (1988) pointed out that protein content in the liver of fish (peters) decreased after given the insecticide monocrotophs. Results of this work go in agreement with Farrag (1996), who found that the treatment of rats with profenophos caused a weak reactivity of protein content in liver, kidney and stomach.

Increase in protein content was noticed in the groups of rats treated with each of ginseng and vitamin $\mathrm{C}$ and profenophos in comparison with group of rats subjected to profenophos only. Zhang (1992), reported that the treatment of rats with ginseng caused increased amount of ribosomes in rough endoplasmic reticutum in cells, reflecting their ability to stimulate protein synthesis. According to Onosaka et al., (1987) the vitamin C is an effective antioxidant which can protect $\mathrm{SH}$ groups of metallothionien and other proteins against oxidation.

In the present work the treatment of rats with profenophos showed a decrease in DNA content in liver and kidney cells. Results of this work are in agreement with Aschner (2000) and Bagchi et al., (1993), they found that the treatment of guinea pigs with organophosphorous compounds caused inhibition in DNA content. Rashwan et al., (1992) demonstrated a decrease in nucleic acid content after treatment of mice with kepon.

In the present work the treatment of rat with ginseng prior to profenophos, led to improvement in DNA, protein and glycogen content in liver and kidney cells. These effects may be due to the antioxidant nature of ginseng (Nishino et al., 2001).

\section{Conclusion :}

Generally the liver and kidney were extensively impaired both histologically and histochemically under the effect of profenophos. Vitamin $\mathrm{C}$ and ginseng have protective effects against the a diverse effects that induced by organophosphorous insecticide (profenophos) in rats. 


\section{Fatma A. Morsy}

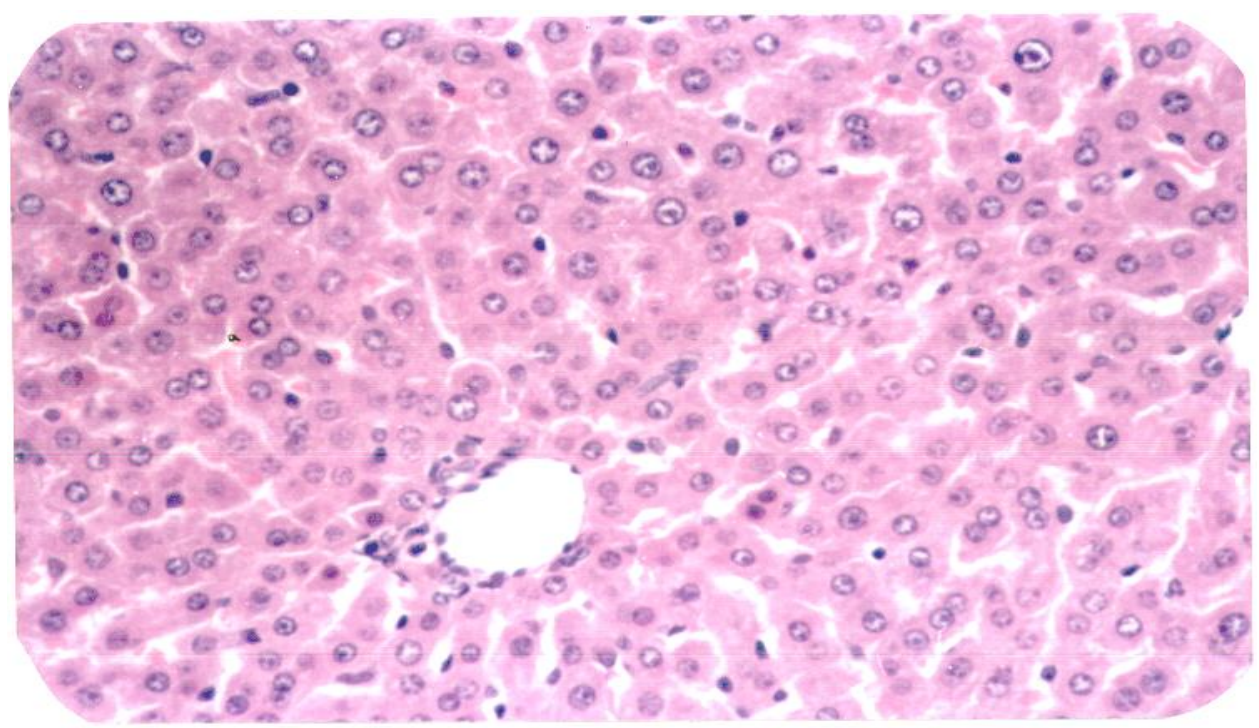

Fig. (1): Section of the liver of control rat showing normal histological structure of hepatic lobules and central vein (Hx \& E x200).

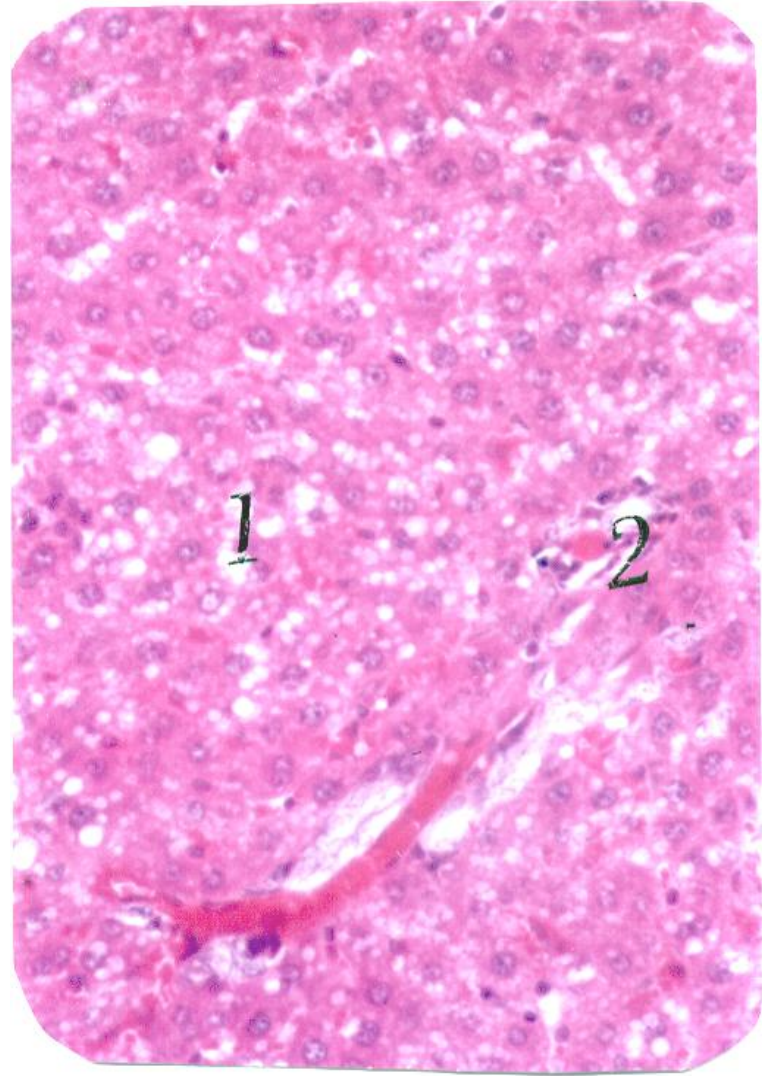

Fig. (2): Section of the liver of a rat treated with profenophos showing fatty changes (1), congested portal tract (2).

(Hx \& E x200)

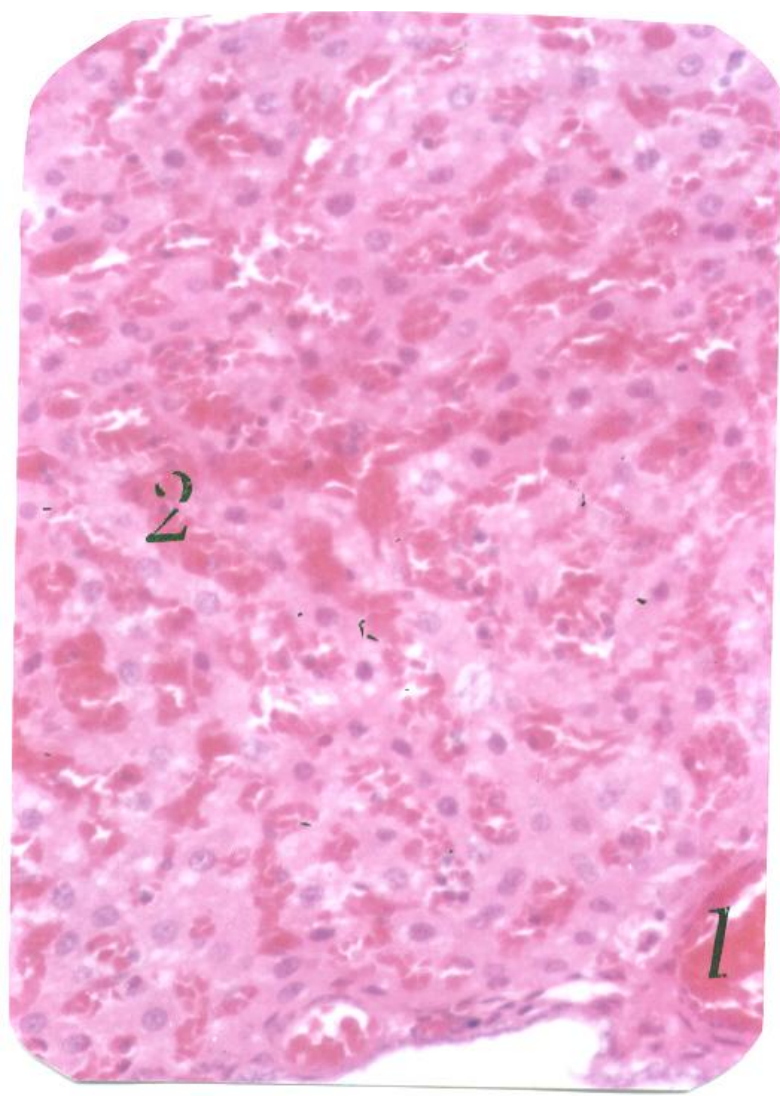

Fig. (3): Section of the liver of a rat treated with profenophos showing dilated and congested central vein (1), the dilated blood sinusoids are filled with red blood cells (2).

(Hx \&Ex 200) 


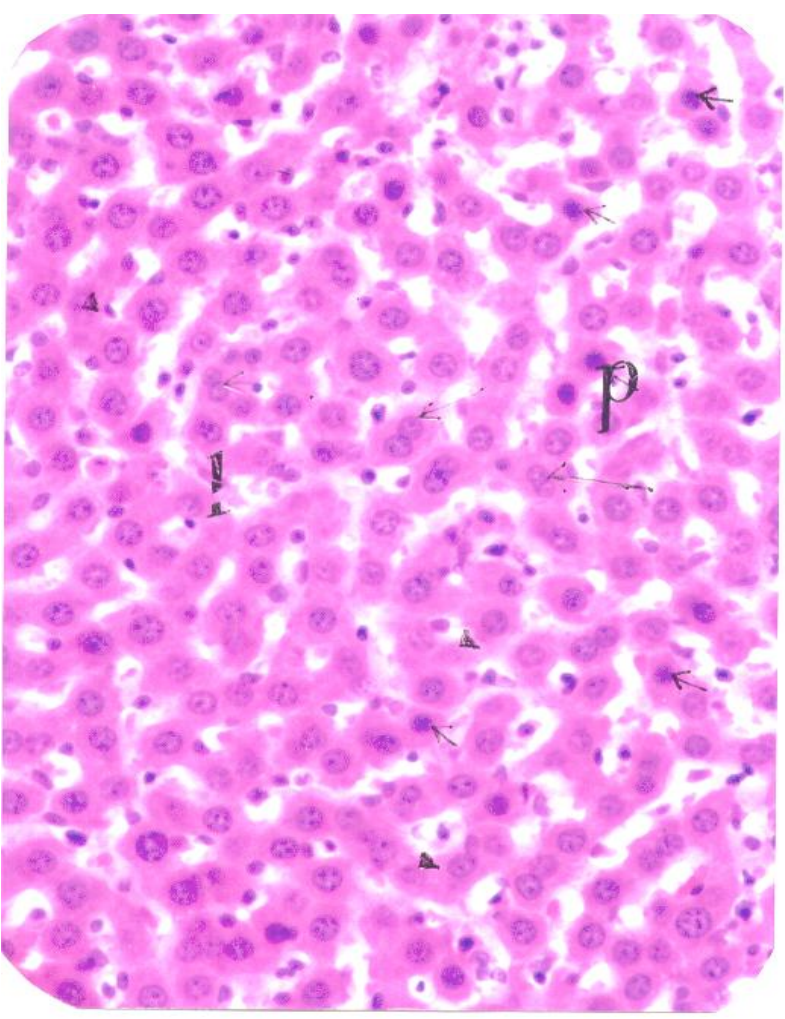

Fig. (4): Section of the liver of a rat treated with vitamin $\mathrm{C}$ and profenophos showing an increase in number of kupffer cells (1) in dilated blood sinusoids (2). Pyknosis (p).

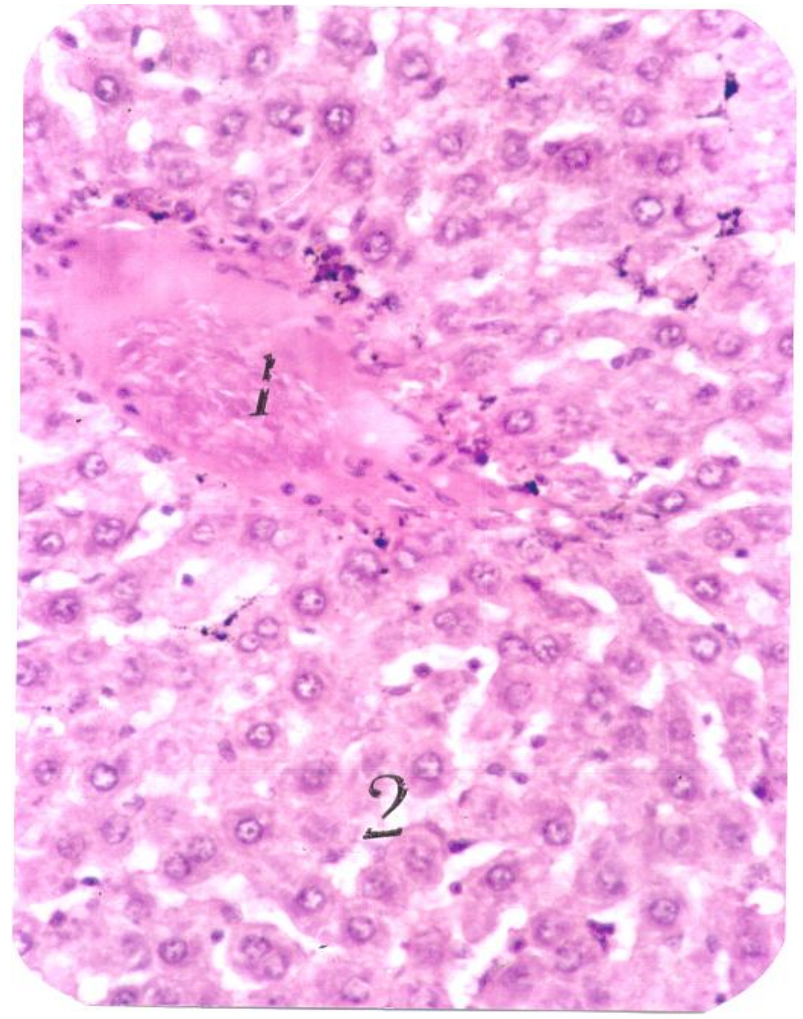

Fig. (5): Section of the liver of a rat treated with ginseng and profenophos showing dilated and congested central vein (1) and blood sinusoids are also dilated (2)
(Hx \&E x200).

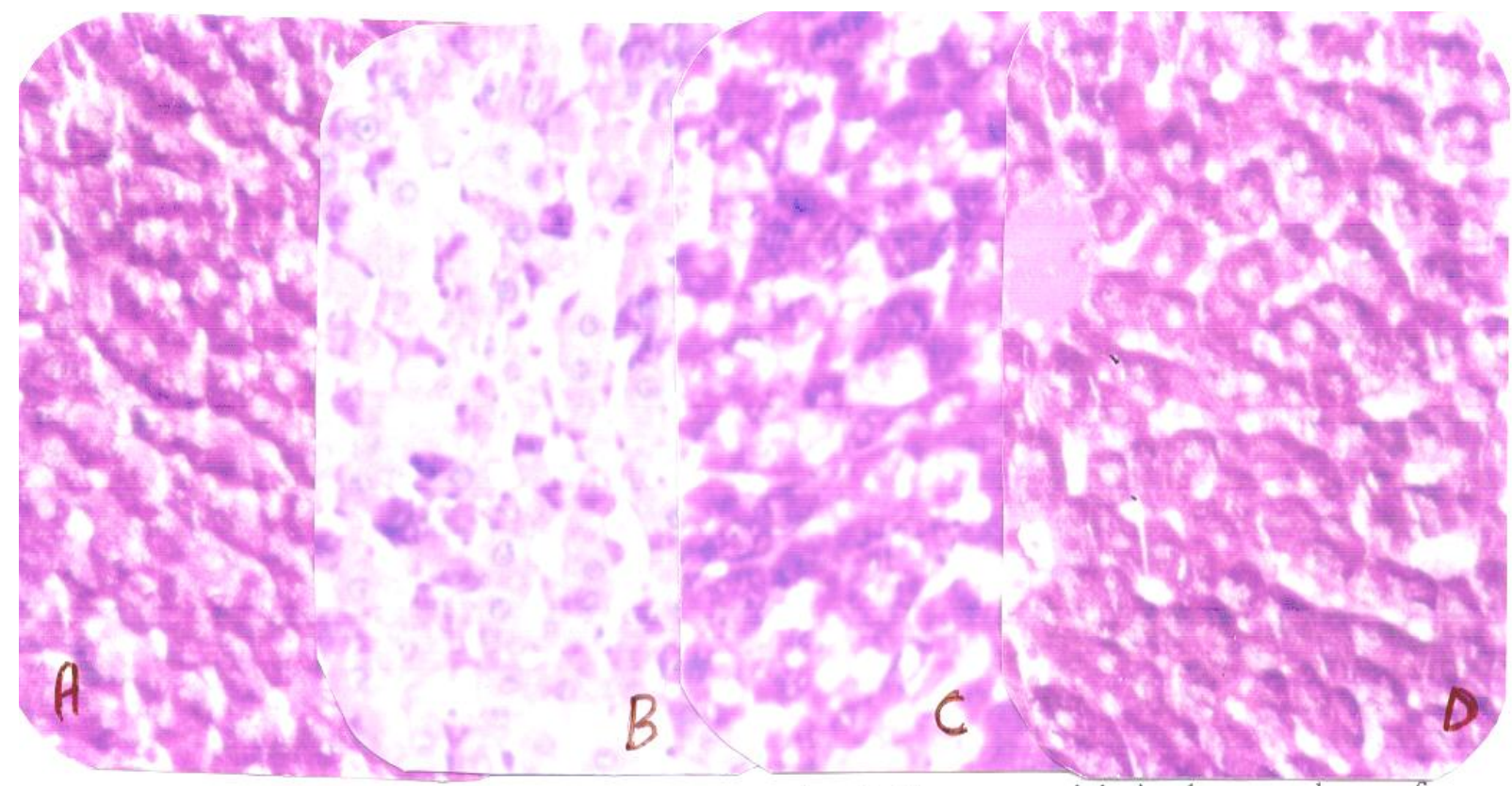

Fig. 6: section of the liver of a rat showing PAS+ve materials in the cytoplasm of hepatocytes (A) Control. (B): Treated with profenophos : showing decrease stainability of PAS+ve materials. (C): Treated with vitamin $\mathrm{C}$ in combination with profenophos showing moderate increase in glycogen content. (D) : Treated with ginseng in combination with profenophos showing marked increase in glycogen content .

(PAS reaction $\mathrm{x} 200)$. 


\section{Fatma A. Morsy}

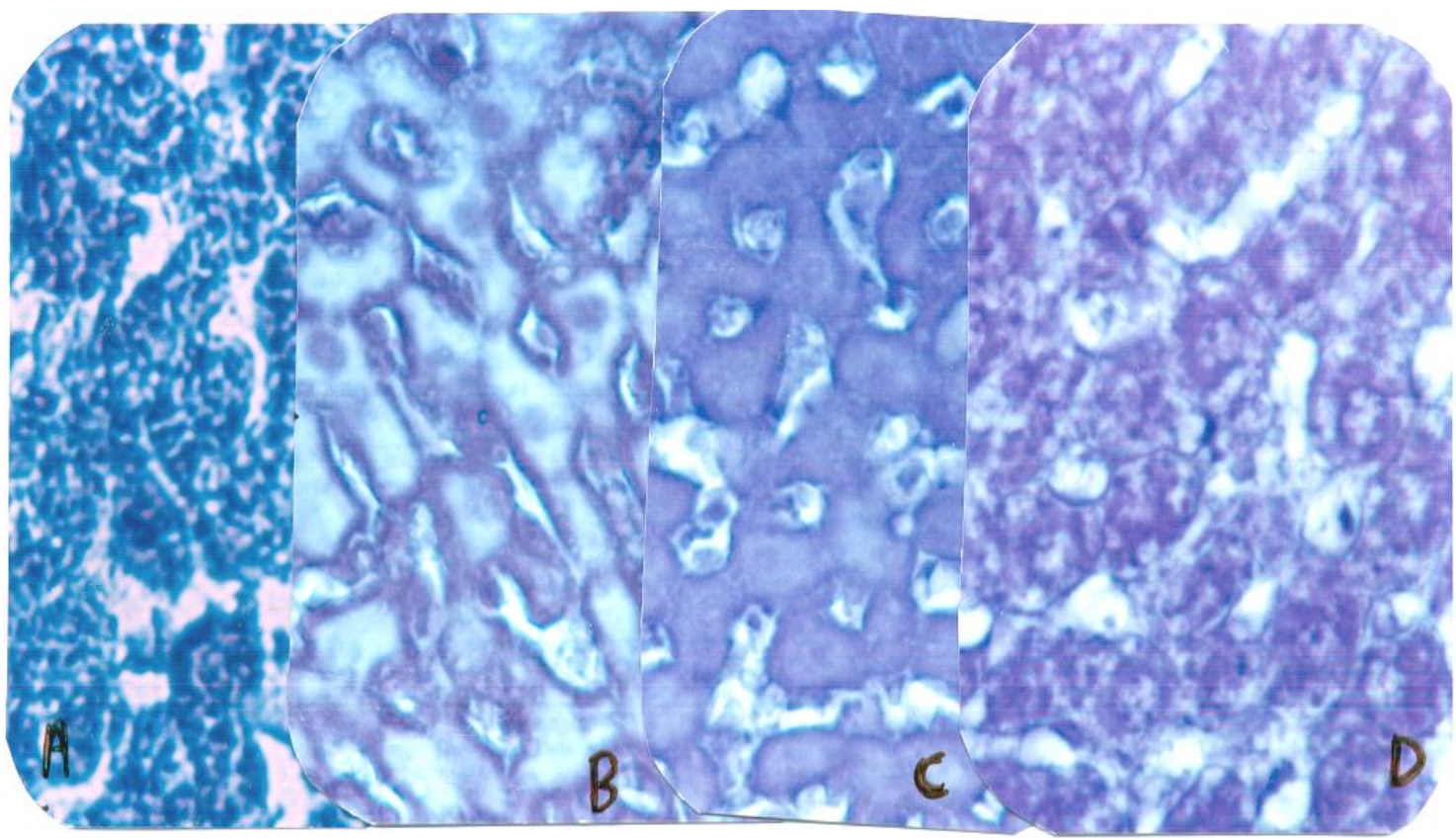

Fig. 7: section of the liver of a rat showing greenish blue protein content in the cytoplasm of hepatocytes: (A) Control. (B): Treated with profenophos : showing marked diminution of protein content. (C): Treated with vitamin $\mathrm{C}$ in combination with profenophos showing slight increase in protein content. (D) : Treated with ginseng in combination with profenophos showing moderate increase in protein content .

(Bromophenol blue stain x 200).

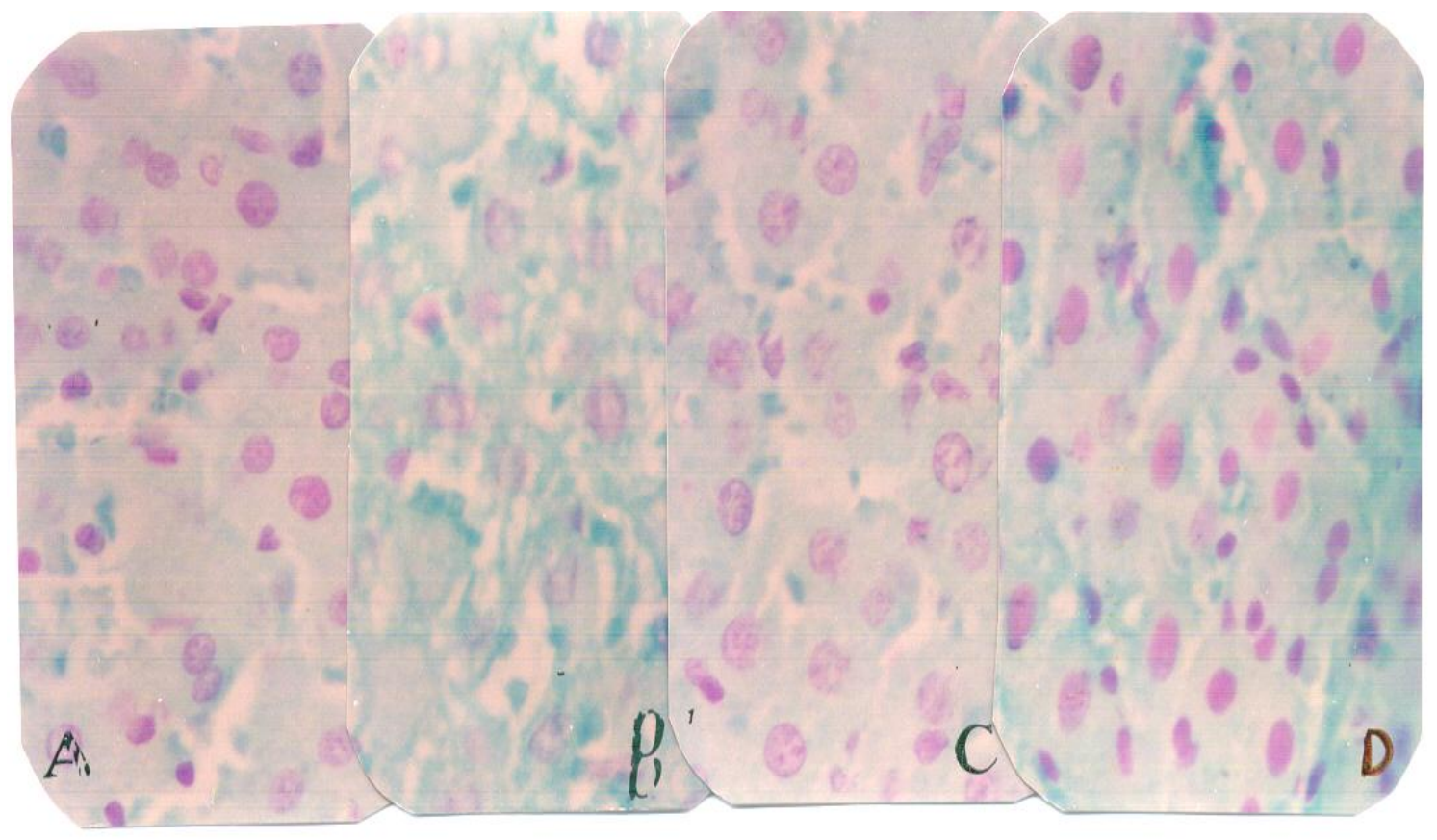

Fig. 8: section of the liver of a rat showing DNA in hepatocytes.

(A) Control. (B): Treated with profenophos : showing a decrease in DNA content. (C): Treated with vitamin $\mathrm{C}$ in combination with profenophos showing increase in DNA content. (D): Treated with ginseng in combination with profenophos showing DNA content more or less like control.

(Feulgen reaction $\mathrm{x} 200$ ). 


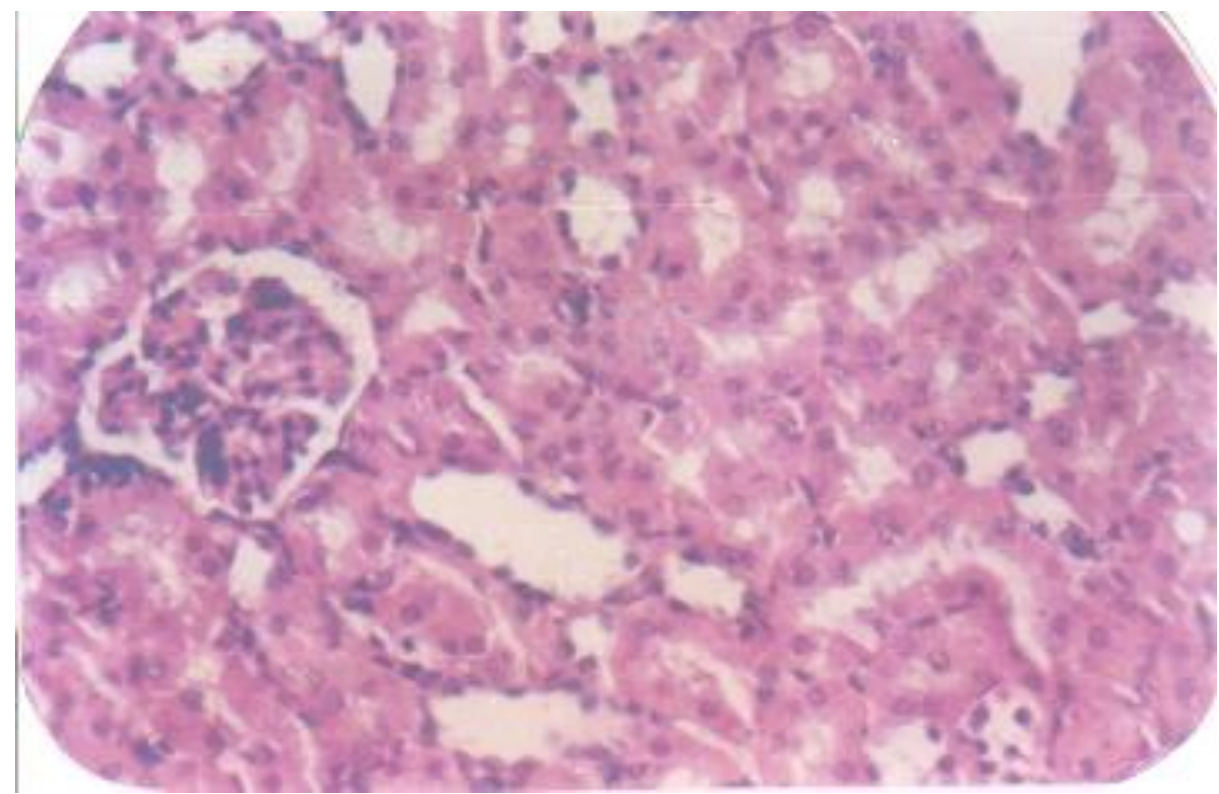

Fig (9): Section of the kidney of control rat showing normal appearance glomerulus and renal tubules.

( Hx \& E x200).

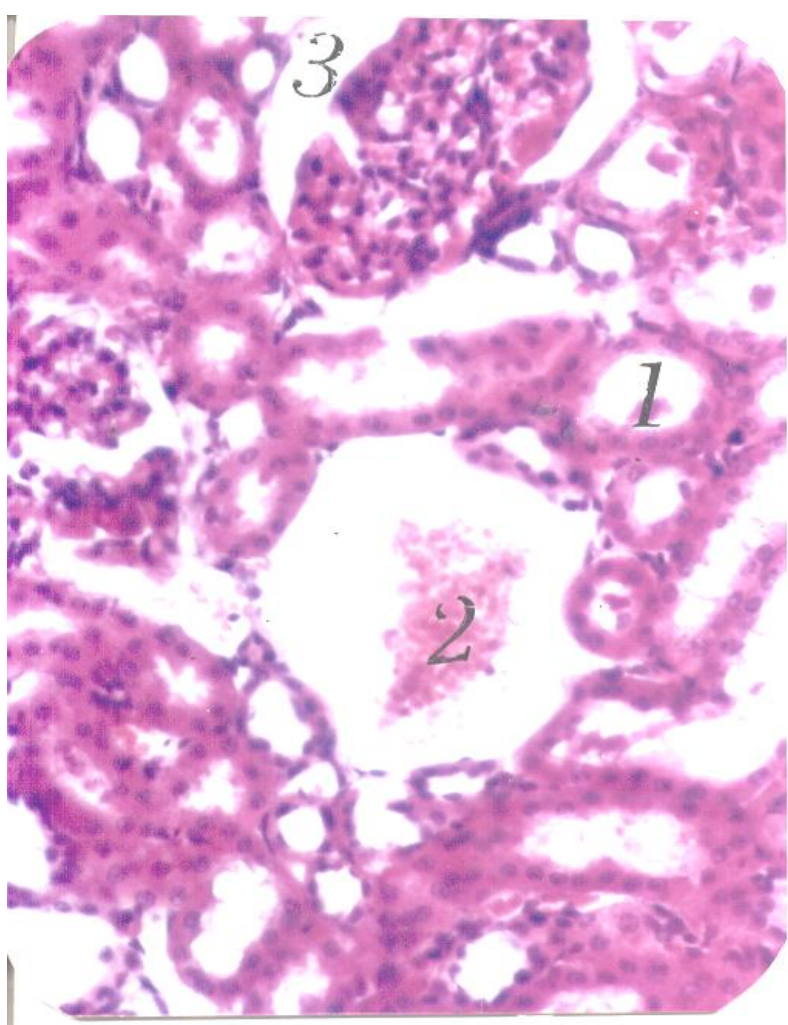

Fig. (10): Section of the kidney of a rat treated with profenophos showing cell debris in the lumen of tubules (1) and in dilated interstitial tissue(2). Some glomeruli are degenerated with wide urinary space (3).
(Hx \& E x200).

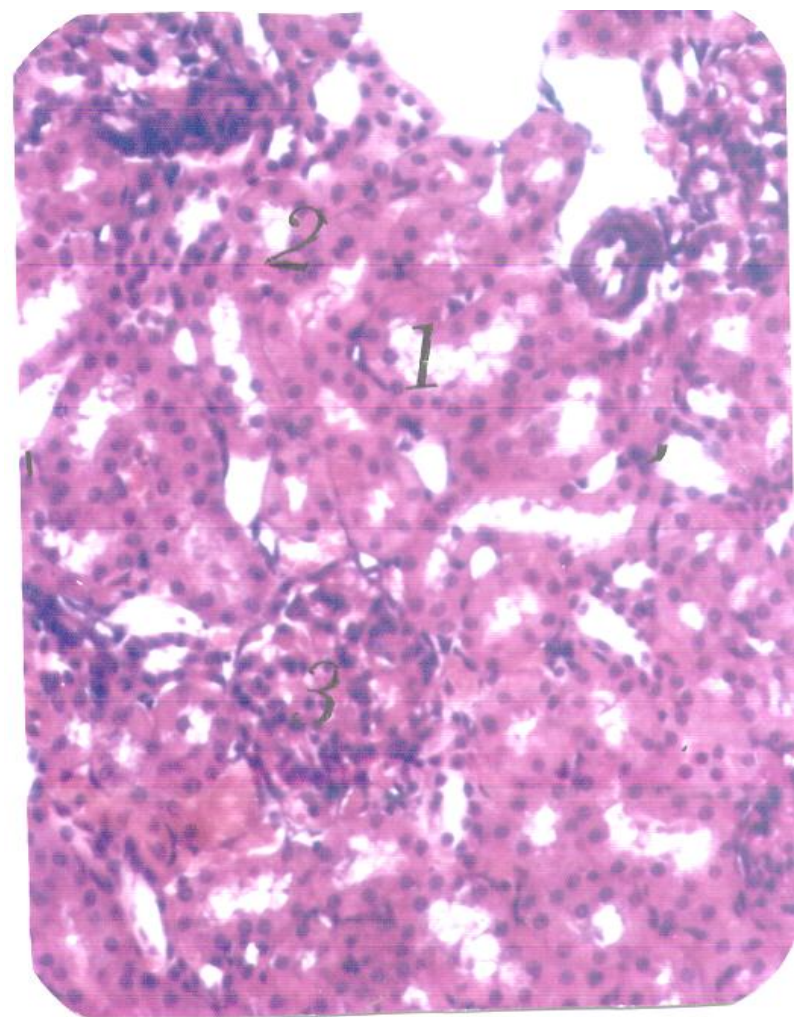

Fig. (11): Section of the kidney of a rat treated with profenophos showing vacuolar degeneration in some tubular cells (1) and pyknosis (2). The glomeruli showed hypercellularity (3)

(Hx \& E x200). 


\section{Fatma A. Morsy}

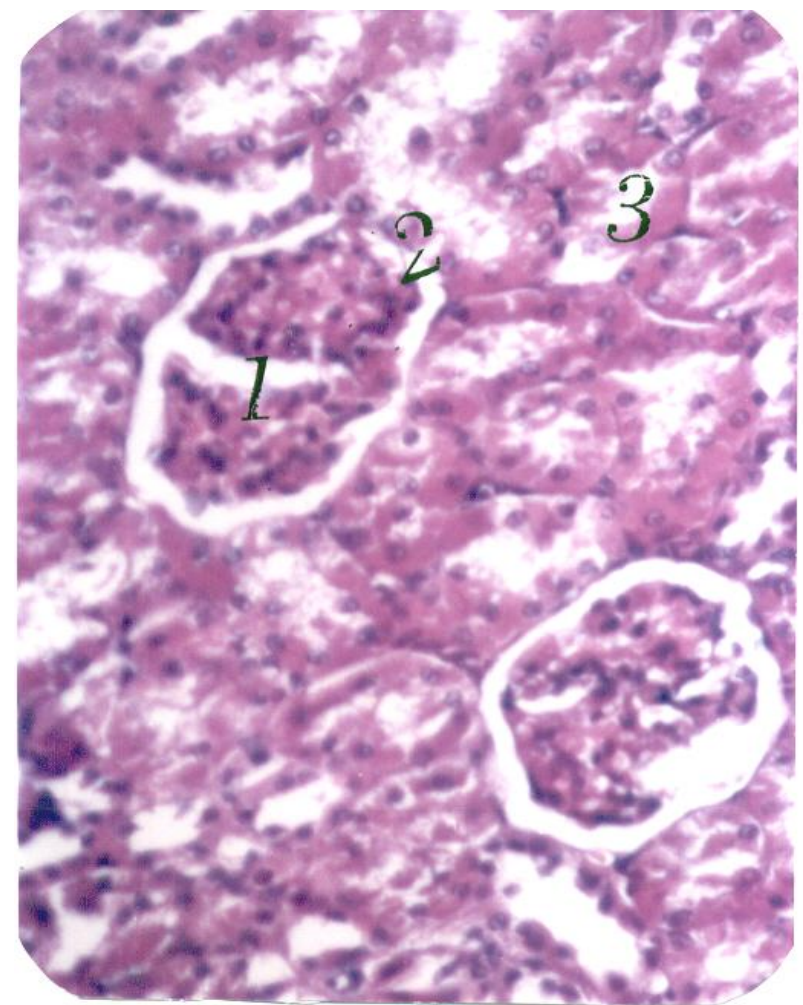

Fig. (12): Section of the kidney of a rat treated with vitamin $\mathrm{C}$ and profenophos showing gomerular lobulation (1). Focal necrosis in some tubular epithelial cells (2) and vacuolar degeneration (3) (Hx \&Ex 200).

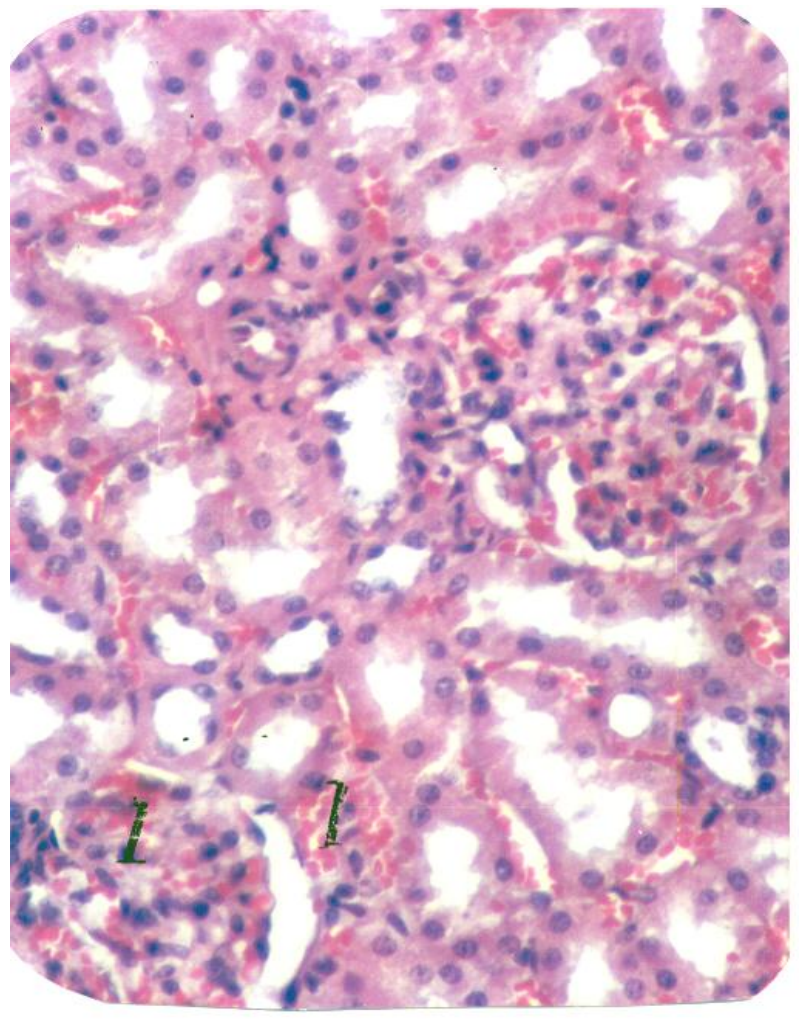

Fig. (13): Section of kidney of a rat treated with ginseng and profenophos showing interstitial and interglomerular haemorrhage (1), increased signs of degeneration (2)

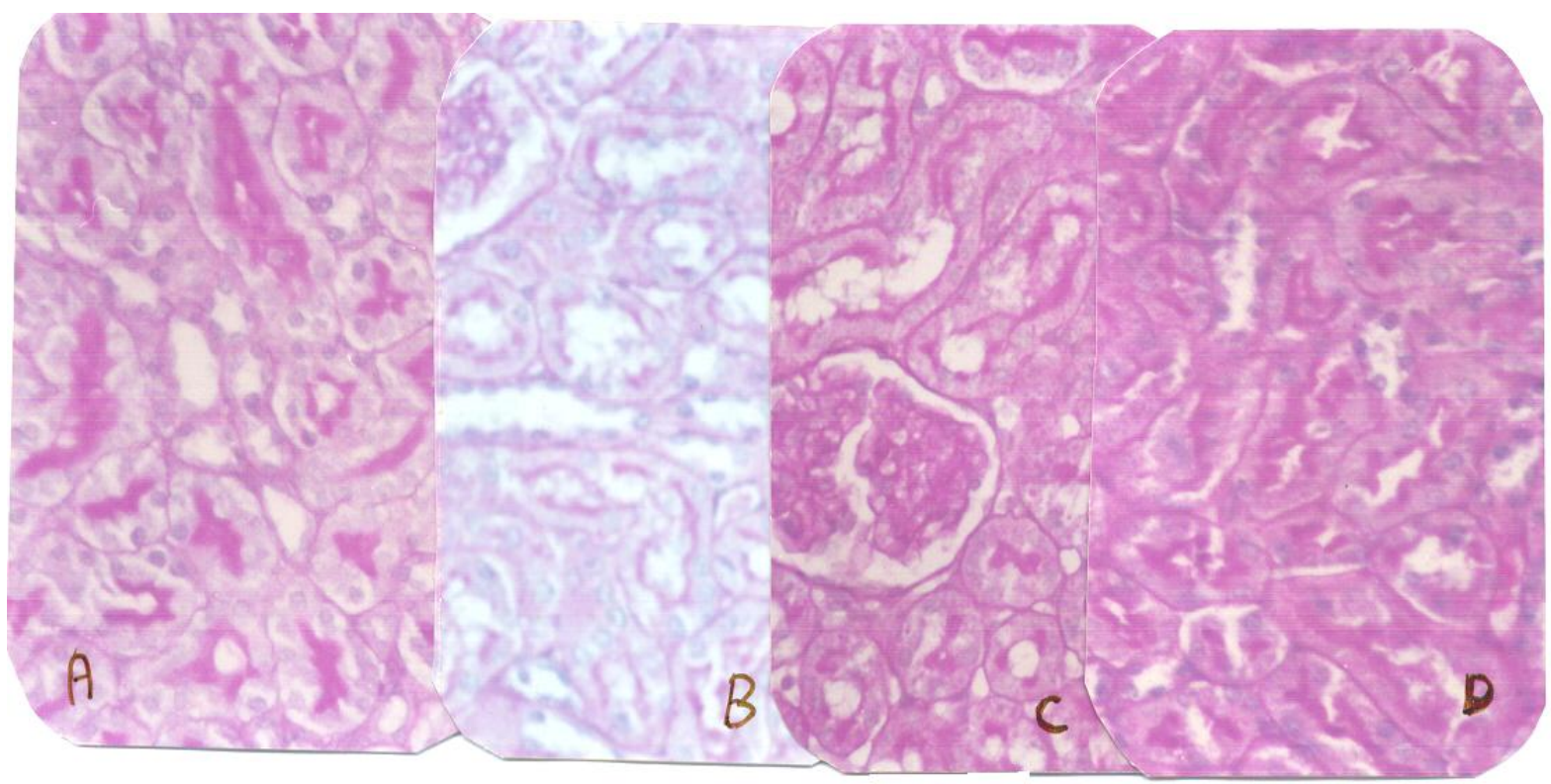

Fig. 14: section of the kidney of a rat showing PAS+ve materials in the basement membrane and brush border of tubules.

(A) Control. (B): Treated with profenophos : showing decrease stainability of PAS+ve materials. (C): Treated with vitamin $\mathrm{C}$ in combination with profenophos showing moderate increase in glycogen content. (D) : Treated with ginseng in combination with profenophos showing marked increase in glycogen content .

(PAS reaction $\mathrm{x} 200$ ). 


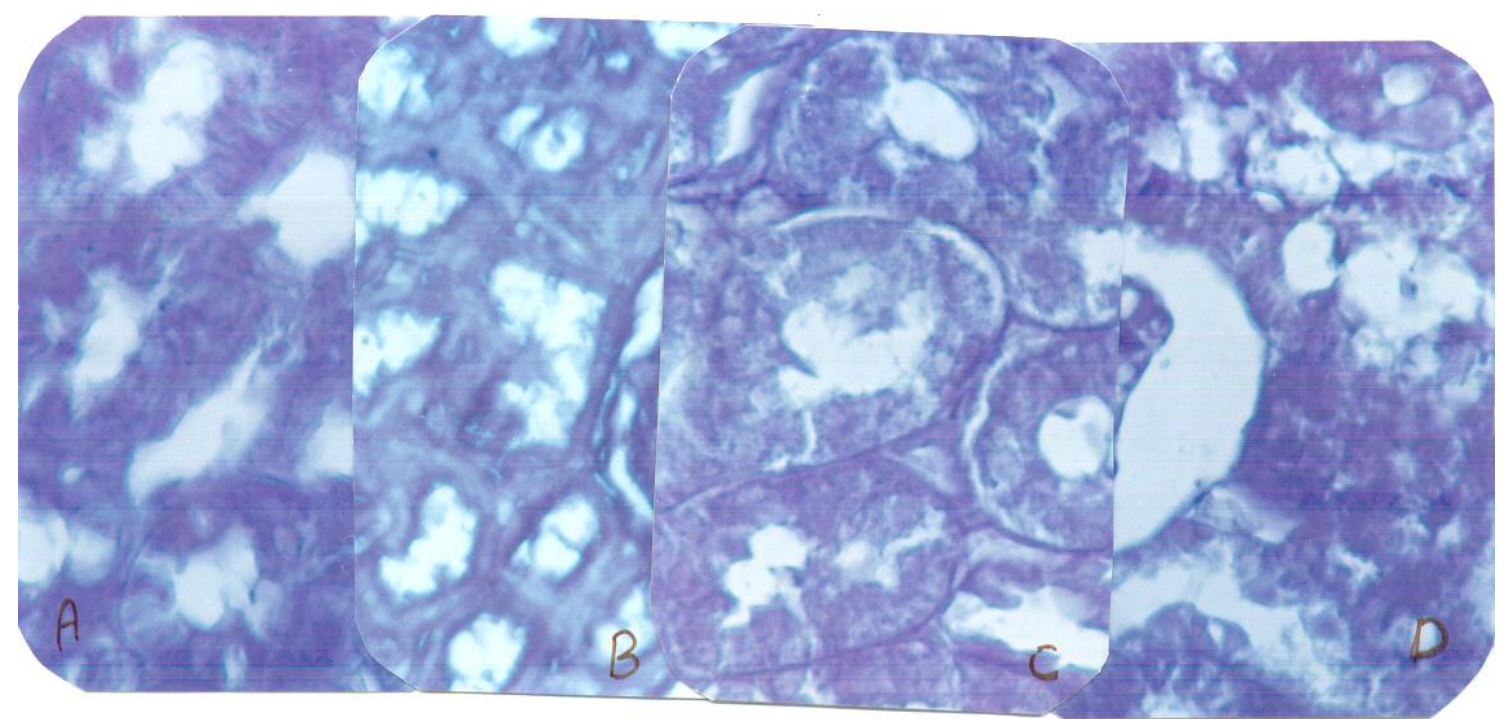

Fig. 15: section of the kidney of a rat showing greenish blue protein content in the cells of renal tubules and renal corpuscles.

(A) Control. (B): Treated with profenophos : showing marked diminution of protein content. (C): Treated with vitamin $\mathrm{C}$ in combination with profenophos showing moderate increase in protein content. (D): Treated with ginseng in combination with profenophos showing an increase in protein content.

(Bromophenol blue stain x 200).

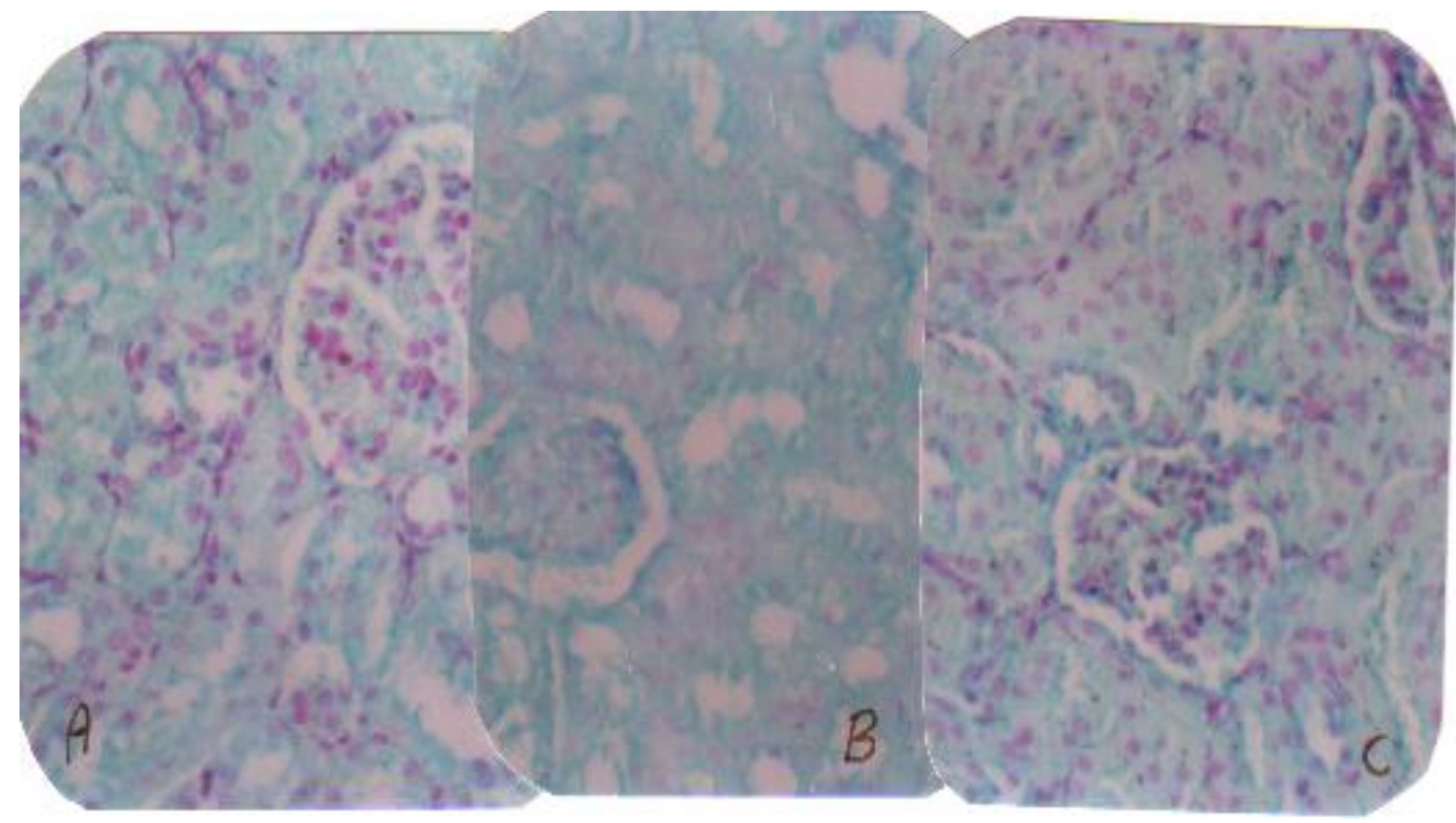

Fig. 16: section of the kidney of a rat showing DNA content.

(A) Control. (B): Treated with profenophos : showing a decrease in DNA content. (C): Treated with each of vitamin $\mathrm{C}$ and ginseng in combination with profenophos showing an increase in DNA content. (Feulgen reaction $\mathrm{x} 200$ ). 


\section{References}

1- Akhter, M.H. (1985): The fate insecticides in economic animals. In "Progress in Pesticide Biochemistry and Toxicology".

2- Alden, C.I.; parker, R.D and Eastman, D.F. (1989): Development of an acute model for the study of chloromethane diphos -phonate nephrotoxicity. Toxicol. Pathol., 17 (1): 27-32.

3- Aschner, M. (2000): Interactions between pesticides and glia: an unexplored experimental field . Neurotoxicology; 21 (1-2): 175-180.

4- Bagchi, D.; Hassoun, E.A.; Bagchi, M. and Stohs, S.J. (1993): Protective effects of antioxidants against endrin induced hepatic lipid peroxidation, DNA damage and excretion of urinary lipid metab -olism. Toxicol. pathol., 19 (1): 110-116.

5- British Crop Protection Council (1991): Pesticide Manual P. 705. London.

6- Cantoni, C. and Comi, G. (1997): Changes in concentrations of pesticide residues in foods and in human tissue between 1960 and 1996 outbook on agriculture, 26 (1): 47-52.

7- Chakraborty, D.; Bhattacharyya, A. Majumdar, K.; Chalterjee , K.; Chatterjee, S.; Sen, A. and Chatterjee, G.C (1978): Metabolism in rats under chronic toxicity due to organophosphorous insecticides: Effects of suppleme -ntation of $\mathrm{L}$ ascorbic acid in high doses. J. Nutr., 108 (9): 973-980.

8- Chang, M.S.; Lee, S.G. and Rho, H.M. (1999): Transcriptional activation of $\mathrm{Cu} / \mathrm{Zn}$ superoxide dismutase and catalase genes by panoxadiol ginsen osides extracted from panax ginseng. Pytother. Res. Dec., 13 (8): 641-644.

9- Chatterjee, K.; Banerjee, S.K.; Tiwari, R.; Mazumdar, K.; Bhattacharyya, A. and chatterjee, G.E. (1981): Studies on the protective effect of L. ascorbic acid in chronic chlordane toxicity. Int. J. Vitam. Nutr. Res; 51 (3): 245-265.
10- Cho,N.H and Park, C. (1999): Effect of dimethyl methylphosp -hontate (DMMP) and trimthylpho -sphate (TMP) on spermatogenesis of rat testis. Yonsei. Med. J; 35 (2): 198-208.

11- Deng, H.L. and Zhang, J.T. (1991): Anti-lipid peroxidative effect of ginsenoside RbI and RgI. Chin. Med. J. Eng., 104 (5): 395-498.

12- Dich, J., Zahm, S.H.; Hanberg, A. and Adami, H.O (1997): Pesticides and Cancer. Cancer causes control, 8(3): 420-443.

13- Drury, R.A.B. and Wallington, E.A. (1980): Carleton's histological technique. $4^{\text {th }}$ Ed. Oxford, New York, Toronto, oxford University Press.

14- El-Banhawy ， M.; El-Tounsy， M.; Farid, N. and El-Salkh, B. (1990): Histochemical studies on the effect of curacron on the adrenal gland of rat. Egypt. J. Histol.; 13 (2): 207-217.

15- El-Ganzuri, M.A. (1975): Cytological and histochemical studies on mamm alian nerve and liver cells. Ph.D. Thesis. Faculty of Science. Ain Shams University.

16- Farrag, A.R.H. (1996): Ultrastructural and histopathogical studies and residue determination of the in secticide profenophos in the albino rat. M.Sc. Thesis. Faculty of Science. Ain Shams University.

17- Feulgen, R. and Rosenbeck, H.C. (1942): Manual of histological technique. Butter worth and Copublishers, Ltd. London, Thetford , Harvehill.

18- Fukuoka, M.; Takahashi, T.; Tanaka, A; Yamaha, T.; Natio, K.; Nakaji.; Y.; Kobyashi, K. and Tobe, M. (1987): Nephrotoxic effect of tris (2,3-dibromopropyl) phosphate on rat urinary metabo -lites: assessment from 13 C-NMR spectra of urines and biochemical and histopathological examination. J, Appl. Toxical., 7 (1): 23-34.

19- Fukuoka, M.; Tanaka, .; Yamaha, T.; Naito, K.; Takada, K. Kabayashi, K. and Tobe, M. (1988). Tris $(2,3$ dibromopropyl) phosphate nephrotox icity in the rat: histological and 
biochemical changes in renal components by 13C-NMR spectra. J.Appl. Toxicol., 8 (6): 411-416.

20- Garcia-Repetto, R.; Martinez, D. and Reptto, M. (1995): Coefficient of distribution of some organophos phorous pesticides in rat tissue. Vet Hum Toxicol; 37 (3): 226-229.

21- Gopinath, G.; Prentice, D.E. and Lewis, D.J. (1987): Atlas of Experimental Toxicological Pathol ogy Lancaster, MTP press limited.

22- Gralewicz, S. and Socko, R. (1997): Persisting behavioural and electroence phalographic effects of exposure to chlorphenvinphos, an organophos phorous pesticide, in laboratory animals. Int. J. Occup. Med. Environ. Health. ; 10 (4): 375-349.

23- Hassan, M.Q.; Numan, I.T.; AlNasiri, N. and Stohs, S.J (1991): Endrin induced histopathological changes and lipid peroxidationin livers and kidney of rats, mice, guinea pigs and hamsters. Toxicol. Pathol., 19 (2): 108-114.

24- Jeong, T.C.; Kim, H.; Park, J., Chang, S.U. H.A; Park, J.D.; Kim, S. and Roh, J.K. (1997): Protective effect of red ginseng sponins against carbon tetrachloride induced hepatotoxicity in Sprague Dawley rats. Planta. Medica., (63): 136-140.

25- Johonson, D.R. (1982): Role of renal cotical sulfhydry groups in development of mercury induced renal toxicity. J. Toxicol. Environ. Health; 9: 119-126.

26- Joshi, U.M. and Desai, A.K. (1988): Biochemical changes in the liver of fish, Tilapia mossambica (peters) during continuous exposure to monocrotophos. Ectotoxicol. Environ. Safty; 15 (3): 272-276.

27- Keum, Y.S.; Park, K.K.; Lee, J.M.; Chun, K.S.; Park, J.H, Lee, S.K. and Kwor, Y.J. (2000): Antioxidant and antitumor promot -ing activities of the methanol extract of heat processed ginseng. Cancer Lett., 13 (15): 41-48.

28- Kim, S.H, Jeong, K.S, Ryu, S.Y and Kim, T.H. (1999): Panax ginseng prevents apoptosis in hair follicles and accelerates recovery of hair modullary cells in irradiated mice. In vivo., 12 (2): 219-222.

29- Konoshima, T.; Takasaki, K. and Tokuda, H. (1999): Anticarcino -genic activity of the root of panax notoginseng. Biol. Pharm. Bull., 22 (10): 1150-1162.

30- Kotb, N.A.; Khalil, H.; Mohamed, F., A. and El-Dessoukey, E.A. (1989): Effects of exposure to Baygon on albino rats biochemical, histological and histochemical studies. J. Leg. Med. \& Forensic. Sci., 1: 54-79.

31- Kumar, V.; Cotran, R.S. and Rabbins, S. (1992): Pathology $5^{\text {th }}$ ed chapter. 14 W.B. Philadelphia Saunders Company.

32- Kurata, M.; Zuzuki, M. and Agar, N.S. (1993): Antioxidant system and erythrocyte life span in mammals. Comp. Physiol., 106 (3): 477-487.

33- Lee, H.C.; Wang, S.G.; Lee.; Y.G., Sohn, H.O.; Lee, D.W, Hwang, S.Y.; Kwak, Y.S.; Wee, J.J.; Joo, W.H.; Cho, Y.K and Moon, J.Y. (2002): in vivo effect of panax ginseng extracts on the cytochrome 450-dependent monoo xygenase system in the liver of 2, 3, 7, 8-tetra-chlorodibenzo-p-dioxin exposed guinea pig. Life Sci.,5, 71 (7): 759-769.

34- Liu, J.; Wang , S.; Lium, H.; Yang, L. and Non, G. (1995): Stimulatory effect of saponin from panax ginseng on immune function of lymphocytes in the elderly. Mech. Ageing Dev.; 83 (1): 43-53.

35- Liu, P.S; Kao, L.S and Lin, M.K. (1994): Organophosphate inhibit catecholamine secretion and calc -ium influx in bovine adrenal chromaffin cells. Toxicology., 31, 90 (1-2): 81-91.

36- Mac-Manus, J.P.A. and Cason, J.E. (1950): Carbohydrate histoch -em -istry studied by acetylation techniques. Periodic acid method. J. Exp. Med., 91 : 651.

37- Mattei, R.; Dias, R.E.; Espinola, E.B.; Carlini, E.A and Barros, S.B. (1998): Guarona (Paullinia Cupano ): Toxic behavioral effect in laboratory animals and antioxidants activity in 
vitro. J. Ethnopharmarol; 60 (2) 111116.

38- Mazia, D.; Drewer, P.A. and Alfert, M. (1953): The cytoche -mical staining and measurement of protein with mercuric bromophenol blue. Biol-Bull., 104: 57-67.

39- McCay, P.B.; Ong, K.L.; Edward, K.L. and King, M. (1979): Possible role of vitamin $\mathrm{E}$ as a free radical scavenger and singlet oxygen quencher in biological system which initate radical mediated reaction. In; Tocopherol, oxygen and Biomembranes (C.de Duve and O.Hayashi, Eds), 4457.

40- Meves, A.; Stock, S.N.; Beyerle, A.; Pitlekow, M.R. And Peus, D. (2002): Vitamin $\mathrm{C}$ derivative a scorbyl palmitate promotes ultravi -olet Binduced peroxidation and cytotoxicity in keratinocytes. J. Invest. Deramatol., 119 (5): 1103-1108.

41- Nagyova, A.; Galbavy, A. and Ginter, E. (1994): Histopathological evidence of vitamin-C protection against cadmi um nephrotoxicity in guinea pig. Exp. Toxic. Pathol., 46: 11-14.

42- Nishino, H.; Tokuda, H. Masuda, M., Satomi, Y.; Okada, Y. and Okugama, T. (2001): Cancer chemopreventation by ginseng in mouse liver and other organ. J. Korean. Med. Sci., (16): 56679.

43- Onosaka, S; D. Kaw.; K.S.; Min; K.O.; Ish, O. and Tanaka, K. (1987): Induced synthesis of metallot -hionein by ascorbic acid in mouse liver . Toxicology., 43: 251-259.

44- Padget , G.E. and Barnes, J.M. (1964): Evaluation of drug activities. Pharmacometrics. Vol. 1. Acadmeic press, London, New York.

45- Rashwan, S.; Riad, F.; Hassan, A.; Khalil, H. and EI Kalawee, S. (1992): Effect of estrogen and kepone injection on cyto-archite -ctural organization and histoche -mical pattern of liver. Bull. Nut. Inst. Cairo. Egypt., 12 (1): 78-92.

46- Rijnkels, J.M. Moison, R.M., Podd, E. and Vanhenegquwn, G.M. (2003): Photoprotection by antioxidants against UV radiation induced damage in pig skin organ culture. Radiat. Res., 159 (2): 210-217.

47- Sapper, H., Kong, S.O., Paul, H.H. and Lohmann, W. (1982): Toxic and drug induced hepatitis. In: Disease of the liver, $4^{\text {th }}$ Ed. edited by Schiff L., pp.604-710. J.B. Lippincot, Philadelphia.

48- Shalaby, A.A. (1985): Effect of cyolane on the cytology and histoch emistry of the ileum of Clarias lazera. M.Sc. Thesis - Faculty of science. Zagazig University.

49- Sies, H. (1985): oxidative stress: Introductory remarks., (1-8) A cadmic press, New York.

50- Siva Parasado, K.; Sambasiva, K.R.S. and Ramana, K.V. (1983): Effect of parathion on tissue ionic changes in fish channa punctatus. Geobios (JODHPUR); 10 (2) : 60-62.

51- Sohn, H.O.; Lim, H.B.; Lee, Y.G.; Lee, D.W. and Kim, Y.T (1993): Effect of subchronic administration of antioxidants against cigarette smoke exposure in rats Arch. Toxicol; 67 (10): 667-673.

52- Sullivan, J.B., and Blose, J. (1992): Organophosphate and Carbamate insecticide. In hazardous materials toxicology: Clinical principles of environmental health (Sullivan, J.B. and Krieger, G.R. eds) p.1026. Baltimore, William \& Wilkins.

53- Sxi, K; Umemura, T.; Takagi, A.; Hasegawa, R. and Kurokawa, Y. (1992): The protective role of glutathione cysteine and vitamin $\mathrm{C}$ against oxidative DNA damage induced in rat kidney by potassium bromate. J. Cancer Res., 83 (1): 45-51.

54- Torki, M.A.; Abd Elrahman, A.A.; Sobhy, H.M. and Mohamed, I.E. (2001): Comparative study of the toxic effect of the organopho -sphorous insecticide (Profenophos) and Microbial Pesticide (Biofly) on rats. J. of the Egypt. Society. Toxicology., (24): 29-36.

55- Tran, Q.L.; Adnyano, I.K.; Tezuko, Y. Saiki, I. Kurashige, Y.; Tran, QK and Kadota, S. (2002): Hepatoprotective effect Majonoside $\mathrm{R}_{2}$ 
the major saponin from vietnamese ginseng (panax vietnamensis) . Plata. Med., 68 (5): 402-406.

56- Trommer, B.; Bottcher, R.; Poppi, A.; Hoentsch, J.; Wartewig, S. and Neuber, R.H. (2002): Role of ascorbic acid in statum corneum lipid models exposed to uv irradiation. Pharm. Res., 19 (7): 982-990.

57- Umnova, N.V.; Michurina, T.L.; Smirnova, N.I.; Alksandrova, I.V. and Poroshenko, G.G. (1991): Study of antimutagenic properties of bioginseng in mammalian cell in vitro and in vivo. Biull. Eksp. Biol. Med., 111 (5): 507-509.

58- Wu, Z.S. (1990): Clinical and ultrastr uctural studies on 8 cases of metham idophos toxicologic myopath chung huaping-U-Hsueh-Tsa-Chih., 19 (14): 303-305.

59- Xiaoguang, C.; Hongyan, L.; Xiaohong, L.; Zhaodi, F.; Yan, L.; Lihua, T and Rui, H. (1998): Cancer chemopreventive and therapeutic activities of red ginseng. J. Ethmopharmacol., 60 (1): 71-80.

60- Xie, Z.C.; Qian, Z.K.; Lium, Z.W. (1993): Effect of ginseng on antiperoxidate injury in mycocar -dium and erythrocytes in streptoz -ocin induced diabetic rats. Chung Kuochung His. T. Chiech. Ho Tsa-Chih, 13 (5): 289-290.

61- Zhang, D.Y. (1992): Protective effects of ginsenosides on warm ishemic damage of the rabbit kidney. ChingHua-I-Hsueh-Tsa-Chih-Taipei; 42 (2): 84-95.

62- Zhang, J.G., Tirmenstein, M.A.; Nicholls-Grzemski, F.A. and Fariss, M.W. (2001): Mitochondrial electron transport inhibitors cause lipid peroxi dation and independent cell death: protective role antioxidants. Arch. Biochem. Biophys., 393 (1): 87-96.

63- Zhao, Z.C.; Xie, K. Q. and Song, Y.L. (1987): Test of acute toxicity of Beauveria bassioana candida to mammalian animals. Chinese J. of Biological control; 3 (3): 124-126.

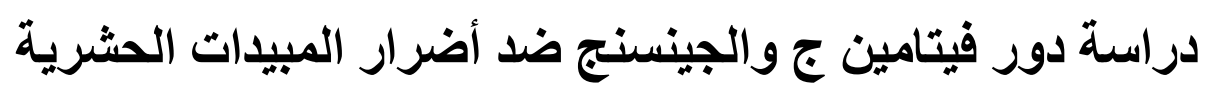




\section{(البرفينوفوس) على كبل وكلى ذكور الجرذان البيضاء

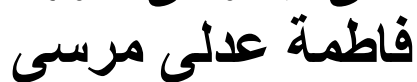

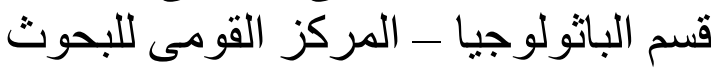

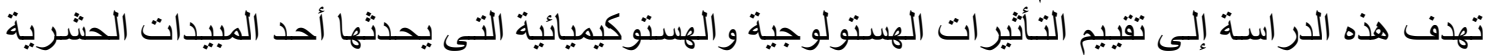

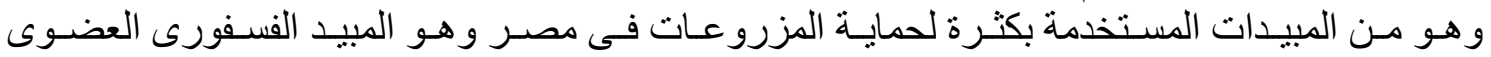

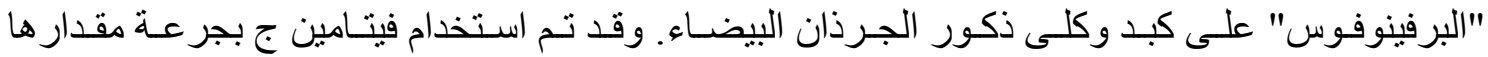

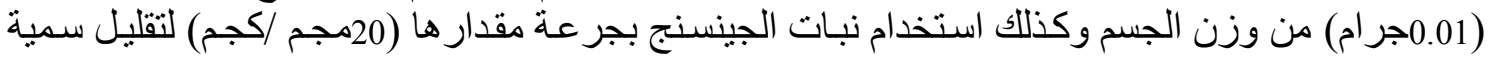

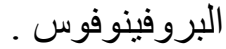

وقد استخدم فى هذا البحث عدد 72 من ذكور الجرذان البيضـاء أوز انهم مـا بين 120 -150 جرام

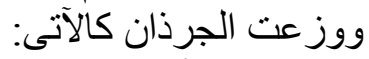

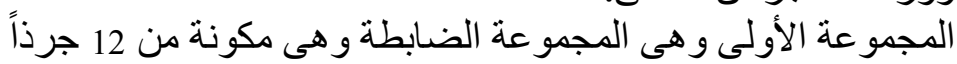

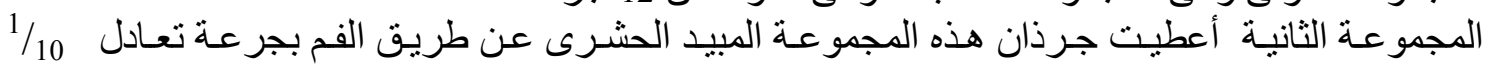

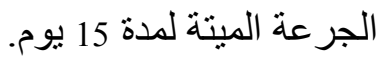
المجمو عـة الثالثة تم معالجتها بفيتامين ج قبل تجريعها بالمبيد الحشرى بحو الى 10 دقائق ويعطى المبيد

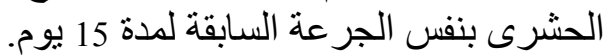
المجمو عة الرابعة تم معالجتها بنبات الجينسنج بجرة عة مقدة مقدار ها (20 مجم/كم) قبل تجريعها بالمبيد الحشرى بحو الى عشرة دقائق لمدة تمعة 15 يوم. المجموعة الخامسة تم معالجتها بفيتامين ج مقدارها (0.01 جرام) من وزن الجسم عن طريق الفم لددة 15 المجمو عة السادسة تم معالجتها بنبات الجينسنج بجر عة مقدار ها (20 مجم / كجم ) لمدة 15 يوم .

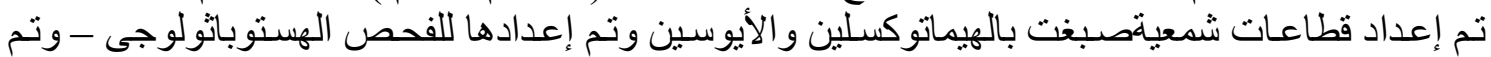
إعداد صبغات للفحص الهستوكيميائى وهى طريقة البير أيوديك شيف لعديدات التسكر المخاطيـة وطريـق

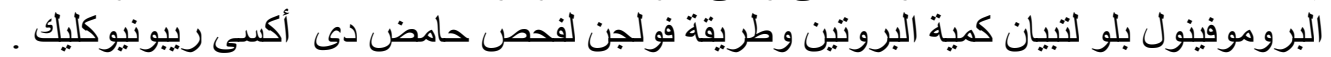
وقد أظهرت نتائج تلك الدر اسة مايلى :

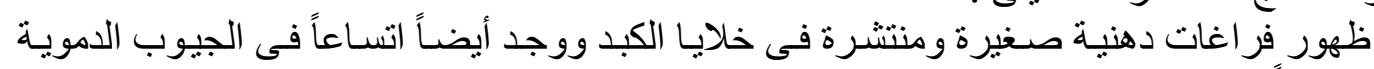

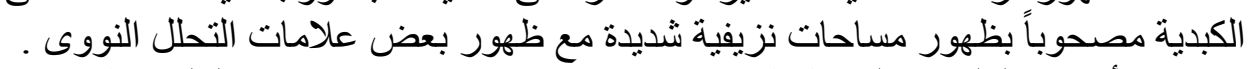
أما فى الكلى فقد لوحظ ظهور مساحات نزيفية منتشرة فى نسيج الكلى وظهور إرتشاح من الخلايبا

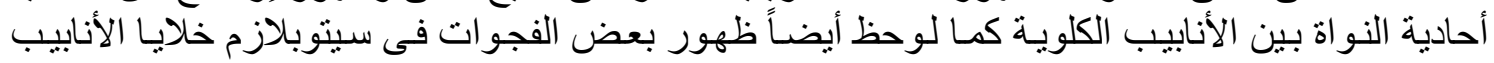

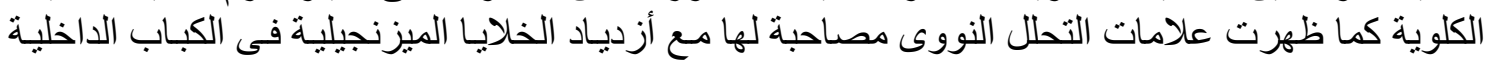

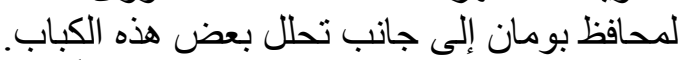

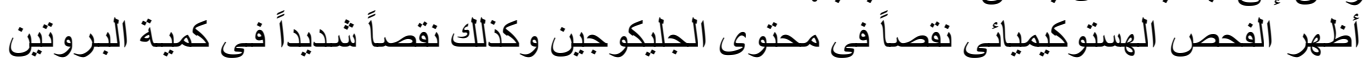

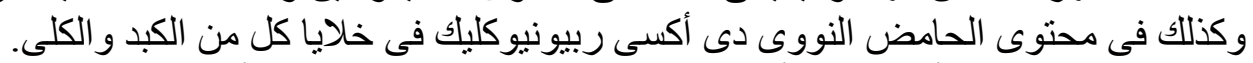

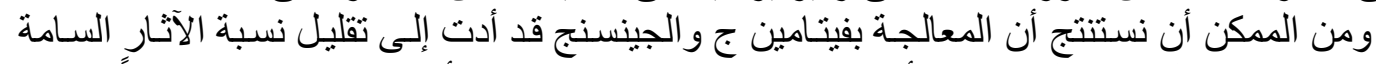

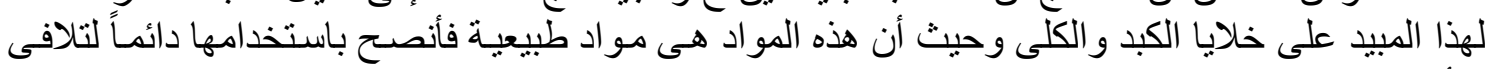

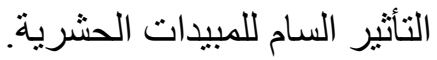

